\title{
11. Welfare, labour and austerity: resistances and alternatives through women's gaze
}

\author{
Maria Paula Meneses, Sara Araújo and Sílvia \\ Ferreira
}

\subsection{INTRODUCTION}

Rights, progress and efficiency come together in the narrative over which the European Union (EU) was built. However, there is a growing awareness on the faultiness and mechanisms that still limit access to justice and the deepening and strengthening of social justice in the European project, as the ETHOS project sought to address (see Chapter 1). High expenditure on social protection, when compared with other realities, grounded on the principles of solidarity, equality and social cohesion represent the soul of the EU (Vaughan-Whitehead 2015). The European Social Model (ESM) was conceived as a unifying and protective umbrella that should strengthen the rather fragile European identity, distinguish Europe from North America and provide tools to protect citizens from uncontrolled neoliberalism (Hermann 2017).

There are multiple expressions of how the EU project has deviated from its initial objectives. Cuts in social policies, youth unemployment and precariousness, the increasing of inequalities and social exclusion, the narrative of the inevitability of welfare state retrenchment and the democratic deficit are some of the signs. At the core of this chapter is the idea that European welfare and employment regimes are experiencing a convergence towards neoliberalism with nefarious results for distribution and social justice, with an extra burden being placed on families in which women play a significant role. Defined as 'a political project that is justified on philosophical grounds and seeks to extend competitive market forces, consolidate a market-friendly constitution, and promote individual freedom' (Jessop 2013, p. 70), the ongoing neoliberal policies have dangerous consequences for democracy and citizenship that are here addressed with a focus on gender inequality in the workplace, women's resistances and alternative projects. 
Reforms to the ESM started in the 1990s. It was however after the 2008 economic and financial crises that changes had a deep impact on the ESM. The leading question of this chapter is how the austerity discourses, translated into policies and laws in the context of the recent crises, have affected EU democracies and citizens' rights. This implies a triple focus: (1) on austerity in the books, that is, the political and legal path chosen by European institutions and member states; (2) on austerity in action, addressing how those choices impacted citizens' vulnerability; (3) on institutional and non-institutional processes of resistance and coping. Considering that gender analysis has been high on the European agenda since the 1970s and still dominates the representation of European values we opted to focus on the vulnerabilization of women by the attacks to the welfare state.

With the aim of addressing misrecognition and vulnerabilization, this chapter analyses the mechanisms that, at various institutional levels, impede parity (Meneses et al. 2018a). For vulnerable groups, such as women, in order to secure 'participatory parity' it is fundamental to analyse both the institutions and economic structures of redistribution (Fraser 2000). For Nancy Fraser, 'participatory parity' as a matter of justice involves being able to 'participate as a peer in social life'. The lesser social value assigned to women, including the idea that they are of less social worth - misrecognition -, is an obstacle to achieving that goal (Fraser 2000; see also Chapters 13 and 14).

This chapter, building upon theoretical and statistical analysis with empirical data collected through case studies in six countries (Austria, Hungary, the Netherlands, Portugal, Turkey and the UK), aims to identify some of the dominant fault lines that limit access to redistributive justice, with a focus on the economic sphere. In parallel, and by discussing the exclusionary processes that legitimate various forms of (in)justice in contemporary Europe (that affect how justice and fairness is (socially) constructed and experienced), it aims to contribute to the ETHOS main goal: an empirically informed European theory of justice.

We start by addressing the common ground of the EU project under the ESM and proceed with the analysis of the neoliberal turn. We then explore the legal and political discourses used to overcome the crisis, as an intensification of a previous trend. This is followed by a discussion of the consequences of the EU political choices for people's lives, with special emphasis on women. Before concluding, we focus on the other side of the same story, asking what kind of resistances, protests and alternatives emerged during the crisis. 


\subsection{THE EUROPEAN HETEROGENEITY UNDER THE ESM}

The ESM never meant homogeneity. There were always differences between welfare systems and employment regimes in different countries. Those differences are crucial to explain the uneven impacts of the neoliberal turn and the 2008 crisis.

Gøsta Esping-Andersen's (1999) typology of welfare models retains explanatory capacity. According to this typology, Europe has three main welfare models of redistribution: (1) a liberal one, with low, residual means tested social protection with little decommodification which prioritizes the role of the market in providing welfare (such as the UK and Ireland); (2) a social-democratic model with generous and universal protection, with high decommodification, which prioritizes the role of the state in guaranteeing welfare (such as the Nordic countries); (3) a conservative-corporative model with generous social protection for those in the labour market and gaps of protection for those outside, with low levels of defamiliarization, relying on the social reproduction work done in the household (the case of continental Europe). Later on other authors have included other regimes, namely: (4) a Southern European model, with gaps of protection and residual social protection for those outside the social insurance schemes, social assistance designed not to discourage participation in the labour market and a strong role of the family without active state policies to promote it (Andreotti et al. 2001); (5) Central and Eastern European welfare regimes shaped by their past as planned economies and neoliberal regime changes towards a market economy, described as recombinant welfare states with a mix of market orientation, targeting and universality (Cerami 2008). This typology has been tested for the transformations of the welfare state towards the social investment state and parallels have been identified, thus maintaining the heterogeneity of the ESM (Meneses et al. 2018a).

Labour relations and working conditions, employment protection and protection in case of unemployment are also not the same across the EU. Several employment regimes distribute work and related benefits: (1) the liberal regime in Anglo-Saxon countries with very low levels of coverage of collective conventions and of low labour union affiliation, good coverage of unemployment benefits and low protection from unemployment; (2) the inclusive model in Nordic countries with high coverage of collective conventions and union density, high coverage and high levels of replacement rate of unemployment subsidies, medium levels of unemployment protection compensated by social protection (flexicurity); (3) the dualist regime in the countries of continental Europe characterized by high coverage of collective conventions, 
but medium labour union density, unemployment benefits depending on the employment status with high coverage rate and the highest levels of protection from unemployment; (4) the Southern European employment regimes characterized by a low labour union density but high collective conventions coverage, low unemployment coverage rate like the liberal regime, but higher benefits income and duration and high protection from unemployment; and (5) the East European countries, with low level coverage of unemployment protection, low level of labour union conventions and low union density (Gallie 2013; Lima 2015).

As Bernd Brandl and Barbara Bechter (2019) underline, although collective bargaining systems were generally targeted within the flexibilization strategy and pressure to change these systems by the EU institutions, these attempts met the national institutions and social partners so that the predominant structure of collective bargaining was not radically altered.

\subsection{THE NEOLIBERAL GLOBAL TREND: EFFICIENCY AS A MEASURE OF RIGHTS}

Since the 1980s the data available revealed a continuous growth of social protection expenditure (Abrahamson 2010). However, qualitative changes were taking place in European welfare states, particularly since the end of the 1990s. These changes were a reaction both to the fiscal and legitimacy crisis of the Keynesian welfare state that started in the 1970s and to the Washington Consensus. They could generally be described under the concept of social investment state, coined by Giddens (1998). Social policies became seen no longer as a remedy for market externalities or a hindrance to the economy, but as a tool for economic growth. Some of the agencies that were louder in the 1980s, such as the Organisation for Economic Co-operation and Development (OECD) and the World Bank, changed their position to consider the productive effect of the welfare state in the economy (Abrahamson 2010; Jenson 2010). The Communication from the Commission 'Modernizing and improving social protection in the European Union' argued that social protection systems have the potential to act as a productive factor, contribute to economic and political stability and help European economies to be more efficient and flexible (Commission of the European Communities 1997).

Jane Jenson and Denis Saint-Martin (2003) detected, in the programme of the social investment state, the shifts between the different responsibilities for welfare from the state to families, market and the third sector. This shift was interpreted by the authors as representing a shift from social rights-based citizenship regimes towards social investment regimes. Policies became oriented to the investment in human capital through education; productive social policies to facilitate labour market participation were enacted, through workfare 
policies and investment in social services so that, for example, women could enter the labour market. Moreover, a focus on social inclusion and social cohesion, through selective support to marginalized or social groups at risk shaped many policies, such as for older people; younger people; persons with disabilities, migrants and ethnic minorities (see also Chapters 6 and 7).

Innovation and entrepreneurship became seen as the key to economic growth to be compatible with an effort to face the challenges of the ESM (Jenson and Saint-Martin 2003). The Presidency Conclusions of the Lisbon European Council (2000) affirmed a new strategic goal for the EU: 'to become the most competitive and dynamic knowledge-based economy in the world capable of sustainable economic growth with more and better jobs and greater social cohesion'. ${ }^{1}$ This idea became the backbone of the 2000 Lisbon Agenda and the 2005 Renewed Lisbon Agenda. In 2000, a group of experts produced a report on the future of social Europe considering that Portugal, Ireland, Denmark and the Netherlands were taking the right steps to escape the path dependency of the typical problems of their type of welfare regime; through social pacts in order to achieve wage restraint and flexibility; growing use of activation measures; and an integrated action involving different policy areas and social actors in the fight against poverty and social exclusion (Ferrera et al. 2001).

A new concept came to the fore - flexicurity -, inspired by Dutch and Danish experiences (Wilthagen and Tros 2004). It combined flexibility in the labour market with social security, particularly as social and employment policies became increasingly coordinated at the EU level. The argument was that while labour flexibility allowed businesses to adapt to global competition, social policies could protect workers from the consequences of this flexibility. According to Maria da Paz Lima (2015), this generated the slow dismantling of industrial relations and collective labour rights through a series of policies such as the individualization of the labour contract, the flexibilization of workers' dismissal, the increase of employers' power, wage moderation and reduction of some social benefits, and pressures upon collective bargaining.

Since the signature of the Treaty of Amsterdam, in 1997, the EU reinforced the capacity to influence member states' social and employment policy and overcome the difficulties of coordination, particularly in matters of welfare and employment where member states retained strong autonomy. The Open Method of Coordination (OMC) was a soft law instrument for achieving this convergence. As the next section addresses, the 2008 crisis brought important changes, less apparent discursively, that came to consolidate the austerity paradigm. 


\subsection{THE AUSTERITY PARADIGM AS THE CONSOLIDATION OF THE NEOLIBERAL TREND}

\subsubsection{European Financial Governance}

There are different moments during the crisis initiated in 2008. At first, there was the impression that one could witness the return to demand-side economic policies to promote economic recovery. In December 2008, the European Commission approved the Economic Recovery Plan with expansionist measures to prevent the recessive consequences of the financial crisis on economic activity and employment. This Plan would complement the rescuing of the failing banks by promoting demand, through public spending, tax reductions and direct support to families and small and medium-sized enterprises. These were supposed to be exceptional measures that would allow returning to the budgetary targets of the Economic and Monetary Union once the return to economic growth and job creation was guaranteed (Costa and Caldas 2014). This period lasted until February 2010, in the context of an increasing tension between budgetary stimulus and budgetary consolidation policies.

In March 2010, a ten-year strategy for the economy of the EU - the Europe 2020 strategy - was proposed by the European Commission, with the motto 'smart, sustainable, inclusive growth'. Although it was presented as a follow-up to the Lisbon Strategy, several aspects were different from the previous period: many components of the social OMC were suspended; there was a bias towards fiscal consolidation and economic recovery; and strong control mechanisms were put in place not just on fiscal and economic policy but also on wages and collective negotiation. The struggle against poverty and social exclusion was not included and social reporting was diluted, with tolerance to non-compliance. Gender equality was basically ignored from measures and priorities and affected by the cuts in public jobs and wages and in social welfare and healthcare services (European Women's Lobby 2012).

For the Heads of State or Government of the Euro Area the priorities became competitiveness and budgetary discipline, to be achieved through structural reforms oriented to economic growth. In December 2011, economic governance was strengthened through the Budgetary Compact, with a rule for all member countries to include in domestic legal systems limits to structural and public deficits. The Six-Pack (2011) and the Two-Pack (2013) included measures to reform the Stability and Growth Pact and greater macroeconomic surveillance to reduce public deficits and macroeconomic imbalances and provided the legal basis for the European Semester. This is now a system of enhanced fiscal and macroeconomic surveillance associated with an automatic 
procedure imposing financial sanctions on those countries that fail to comply with the policy recommendations.

Since 2015, with more positive indicators, the new European governance sought to return to the social pillar of the EU. This is evident in the increasing recommendations on social and labour dimensions in the country-specific recommendations of the European Semester. The concern with societal and social challenges reappeared in various documents: for example, in the Five Presidents Report, Completing Europe's Economic and Monetary Union (Juncker et al. 2015), in the Communication from the Commission On Steps towards Completing Economic and Monetary Union (European Commission 2015) as well as in the steps to materialize the proclamation of the European Pillar of Social Rights at the Gothenburg Summit, in 2017 (European Council 2017). This does not mean, however, a consistent concern with the expansion of social policies. For instance, Sonja Bekker (2018) notices that the numerous references to pensions in country reports are often about making pension systems sustainable, including increasing retirement age, with detrimental effects in welfare.

\subsubsection{Social State Retrenchment Packs}

Austerity measures implied the reduction of public expenditure through cutting personnel and social expenses, tax raises to reduce income and consumption in order to reduce budgetary deficit, privatizations, internal devaluation, cuts in the minimum wage and cuts in the public sector (Lima 2015). At a structural level, EU policies targeted particularly social and employment protection and collective bargaining systems, through labour market deregulation, fragmentation of labour relations and erosion of the welfare state. In terms of employment protection, flexibilization affected labour rights and working conditions. For example, one witnessed, in some countries, a dramatic increase in working hours and a reduction in supplementary work pay, the multiplication of atypical contracts, extension of the maximum length of fixed-term contracts (being the case of Portugal). In other countries it meant the maximum renewal of these contracts (such as the case of the Netherlands), severance pay to ease layoffs, a relaxing of redundancy rules, and challenging dismissals made harder (such being the case of the UK, Turkey and Hungary) (Leite et al. 2014).

The EU countries which signed a Memorandum of Understanding with the International Monetary Fund (IMF), the European Central Bank (ECB) and the European Commission (EC) (the Troika) for receiving emergency loans, or those which were under Stand-By Arrangements with the IMF were the ones where these alterations were most acute, such being the case of Portugal. In the Portuguese case, the Troika and the IMF support was associated with 
conditionality of structural reforms in the labour market and the collective bargaining systems, including also wage moderation (Meneses et al. 2018b).

The new EU economic governance framework with the Country Specific Recommendations (CSRs) led to various significant changes in collective bargaining systems at the national level (Brandl and Bechter 2019). Measures reinforcing the obligation to work for unemployed people, reducing the amounts of benefits and restraining the rules of access to unemployment protection took place in various countries, such as Portugal and the UK (Dupont and Anderson 2018; Meneses et al. 2018b). Wage restraint has been a significant boost for the EU and IMF as a measure to promote competitiveness, both for the countries under international bailout and the European Semester CSRs. Besides the impact that the European Semester has had on the different countries, one must also bear in mind how the national differences are played in this context. For instance, whereas the UK government was substantially aligned with austerity and quickly implemented it, others (such as France) had a more moderate approach to austerity.

\subsection{THE SOCIAL CONSEQUENCES OF AUSTERITY}

\subsection{1 (Un)employment}

The crisis and the EU reaction had dramatic effects on employment. Although there was an employment recovery after 2013, it was mainly for higher-paid jobs. In 2016, several countries were in compliance with the Europe 2020 target employment rate of 75 per cent (among them the Netherlands and UK) and others were getting closer (case of Austria, for example). However, several countries lost an important percentage of employees, due to workers' migration. Here, Romania (10.2 per cent), Latvia (16.3 per cent) and Portugal (10.6 per cent) showed critical numbers. In some countries there was employment destruction, in particular core employment, partly replaced by an increase in temporary work and self-employment (the Netherlands and Finland). The UK experienced employment recovery both in core and self-employment (Eurofound 2017).

The crisis hit the manufacturing, construction and agriculture sectors the most, and these jobs do not seem to have recovered. For example, the services sector accounted for 71 per cent of employment in the EU in 2016, and whereas Austria and Hungary experienced small increases in the period 2008-16 (less than 2.5 per cent), Portugal experienced a strong increase (more than 5 per cent) (Eurofound 2017). The UK as well as Portugal experienced increases in high-paid jobs. Between 2011 and 2013, Portugal, on the other hand, experienced employment destruction in mid-paid jobs. Countries that experienced downgrading of employment in terms of the incidence of job 
growth in lower-paid jobs were, for example, Hungary and the Netherlands. Polarization in job growth was experienced in Austria with both lower end and upper end jobs being created (Eurofound 2017).

Although labour market and employment protection deregulation measures targeted particularly permanent employees in the core labour market, an assessment of the consequences of austerity/structural reform measures in core and peripheral EU countries shows, for instance, that insiders in the core countries where not affected, contrary to what happened in the more peripheral countries. In the latter, both permanent and temporary workers were affected by deregulation of employment protection. Here, where protection of outsiders is also weak, reducing protection has much harder effects than in central countries (Prosser 2017). Therefore, recovery is not taking place in the same jobs and in the same way in the different countries, leading to polarization of the labour market overall, with the consequent increase in inequalities.

\subsubsection{Precarization and Flexibility}

Precarity is often associated with deficient social protection, showing that flexicurity seems not to be working in most countries and the model of the Netherlands and Denmark is not easily exported. Labour precarization was a trend prior to the 2008 crisis. However, the crisis made job insecurity worse. During the crisis there has been a reduction of workers in full-time permanent employment (a variation of 59.5 per cent in 2009 to 58.2 per cent in 2016 hides sharp internal differences such as the decrease of core employment in Spain and Finland and an increase in Sweden and the UK), except for the higher-paid jobs, and an increase in part-time and temporary employment (Eurofound 2017).

In 2016, temporary employment was lower than before the recession (14.2 per cent in 2016 to 14.5 per cent in 2006), showing that these trends were already occurring in the labour market as the increase in temporary contracts started taking place before the recession, in 1985 (Eurofound 2018). Countries where temporary employment rates are above the EU average include the Netherlands, a country of flexicurity, and Portugal, a country of precarity (above 20 per cent - Eurofound 2018).

Part-time work, one indicator of labour flexibility, became a trend before the crisis. Using data from the Better Life Index, OECD, ${ }^{2}$ we analysed the proportion of workers in part-time work, that is, of persons who usually work less than 30 hours per week in their main job, by sex, in 2006, 2013 and 2016, that is, before the crisis, at the peak of the crisis and after the crisis in Europe (Meneses et al. 2018a). Part-time work has been increasing in the EU for a long time (for instance, from 16 per cent in 1996 to 20 per cent in 2015). During the crisis, part-time work kept increasing, particularly in involuntary part-time 
work, ${ }^{3}$ from 22.4 per cent of all part-time work, in 2007, to 29.1 per cent, in 2015.

The proportion of women in part-time jobs is much higher than men, which has consequences in terms of social protection, particularly in those countries where benefits are more connected to the employment trajectory, such as in the case of the conservative/corporatist and the Southern European welfare models. The Netherlands, often highlighted as the most successful case of flexicurity, stands out as the part-time ratio represents more than half of women, but the proportion of women in involuntary part-time employment is the lowest (de Vries et al. 2018). Countries such as Austria and the UK also stand out for women's part-time employment, representing around one-third, mostly done on a voluntary basis (Dupont and Anderson 2018; Meier and Apostolovski 2018), a change in the dominant male breadwinner household model replaced by a model where the main income is complemented by the part-time income of the partner, usually female, in the case of Austria, and a trend in the liberal model of the UK, where the market is the first solution for care (Dupont and Anderson 2018).

In Southern European countries, such as Portugal (the country with the lowest numbers of part-time employment for women), voluntary part-time work decreased from 2006 to 2016, but not involuntary work. Numbers by themselves might say very little. Higher rates of full-time employment are not necessarily equivalent to gender equality. It may be a sign of low wages implying a dual breadwinner model, being the reality in Portugal and Hungary (Hungler and Kende 2018; Meneses et al. 2018b) or of lack of adequate part-time job opportunities in the absence of affordable childcare, as the UK study illustrates (Dupont and Anderson 2018).

The data available also indicate polarization between countries and precarization for the Southern European countries regarding women's part-time employment. The sharp increase of women in involuntary part-time employment occurred in European countries severely hit by the austerity measures (for example, in Italy, Spain, Ireland and Greece) and in Hungary. Other countries, however, saw a decline of involuntary women's part-time work until the peak of the crisis in 2013, such as Belgium, Denmark, Finland, Germany and Poland. After 2013 until 2016 there was a reduction in Portugal, Spain and Sweden, but the numbers remained high (Eurofond 2018).

Self-employment is another form of atypical employment and it does not seem to have been affected particularly by the recent crisis. Own-account work is officially recognized by the International Labour Organization (ILO) as contributing to vulnerable employment. Self-employed people are less likely to have formal work arrangements and therefore lack social security protection and a voice at work. In the EU it remains at 15 per cent of all employment, although with country variations. Due to the decline in the primary sector, 
it has declined, among others, in Portugal, whereas it has increased in the UK and the Netherlands. Self-employment in the UK and the Netherlands is promoted with tax advantages, which explains the interest for this form of work. As Dupont and Anderson (2018) stress, with its liberal employment and welfare regime, the UK is paradigmatic in terms of the way the typical industrial model of work is changing, with an increased diversity of employment and work statuses, and uncertain boundaries between the different forms of work, sometimes to be clarified in courts.

Own-account self-employed is an ambiguous category, which may indicate an erosion of the labour status as workers are usually dependent on a dominant single client and are more vulnerable due to its usual small size and the low coverage by social protection. ${ }^{4}$ In Portugal, as in most countries, self-employment is not the outcome of a choice for a new form of work but a structural feature of precariousness. The so-called false self-employment has been a feature of the Portuguese labour market for a long time, and not just in the private sector. As Meneses et al. (2018b) indicate, this implies that although the worker fulfils all the criteria of an employee (for example, a single employer, a workplace, a constant payment) the labour relation is under the form of self-employment. Thus, the worker is extremely vulnerable in terms of employment protection, labour rights and social protection. This situation is facilitated by the legal framework and the enforcement instruments as employers are exempt from the fiscal and legal obligations of dependent work, dismissal happens without penalty and contributions for social security are significantly lower. Attempts at changing this situation have been timid and, more recently, legitimizing the situation of false self-employees. For instance, an unemployment subsidy was created in 2013 for self-employed workers who work for a single company and are economically dependent on this company (in 80 per cent of total income).

\subsection{3 (In)security}

Although austerity and changes in welfare and employment regimes took place in all countries, the Scandinavian countries demonstrated more resilience of their welfare states and the Southern European countries demonstrated their extreme vulnerability. Using data from the Better Life Index (OECD - data for 2006, 2013 and 2016) comparing labour market insecurity - defined as the expected earnings loss associated with unemployment, which depends on the risk of unemployment, the expected duration of unemployment and the expected degree of mitigation that unemployment subsidies provide against the earnings loss - we verify that labour market insecurity is higher in Southern European countries, lower in the Nordic countries and the Netherlands, followed by the countries of the conservative-corporatist model. 
Most of the Central/Eastern European countries are in the second cluster with the highest labour market insecurity.

\subsection{4 (In)dignity}

Precariousness, flexibility and insecurity directly or indirectly affect people's dignity. Not only are people easily humiliated when they have no individual resources and power to react but the instability inhibits the possibility of making plans and deciding about private matters. Regarding the UK, Pier-Luc Dupont and Bridget Anderson state: 'people living precarious lives also found their personal autonomy severely curtailed by power imbalances that allowed not only employers but also jobcentre officials to discriminate or otherwise dominate them with impunity' $(2018$, p. 44). In the case of Portugal, when a couple, in their late thirties, testify they have to submit the decision of pregnancy to the time frame of a fixed-term labour contract and how stressful it might be, we realize how many different forms violence may assume and that European young citizens are submitted to situations that are not compatible with values of freedom and equality (Meneses et al. 2018b). Also precariousness and insecurity associated with the introduction of new technologies (especially the possibility of working online) may result in an assault on citizens' private lives and the absence of defined leisure or rest moments.

\subsubsection{Women's Situation}

We referred above to gender inequality and justice in the labour market. This reality is present in all six countries studied, stressing how part-time work, and particularly involuntary part-time work affects mostly women, with consequences on the redistribution of careers and welfare. This is one of the many aspects of gender inequality, which range from the pay gap to the unequal distribution of care. EU policies have long been oriented to tame these inequalities, namely with anti-discrimination policies, pregnancy and parental protections and the social investment state promoting participation of women in the labour market, including the support for social services for children and the elderly.

The increased participation of women in the labour market is often associated with labour market segregation. There was a substantial concentration of women in low-paid jobs (about 68 per cent) and a lower weight of female work in other jobs (less than 40 per cent in medium-paid jobs and above 40 per cent in high-paid jobs) in 2015. The substantial percentage of part-time work in the EU is done by women (four out of five). Among the voluntary part-time workers, 78.2 per cent are women whereas the percentage for men is only 21.8 (Eurofound 2018). The effects of the crisis combined with a disinvestment in 
policies and agencies promoting gender inequality had several effects in this landscape.

The crisis initially had a more negative redistributive effect in male-dominated sectors such as manufacturing and construction but, in second phase, women also started to lose jobs mainly in service sectors affected by household expenditure cuts and welfare services cuts, for which unpaid work is a substitute. The expected outcome of this was intensification of the unpaid work performed by women (European Union 2012). Still in 2011-13 women experienced less job losses than men and the gender employment gap decreased by 2.5 per cent from 2008 to 2016 (Eurofound 2018).

The gender gap appears to be reducing as men occupy low-paid, typically female jobs and get into a more precarious situation. This results from the disappearance of typically male-dominated jobs and from women's increased presence in high-paid jobs. That is, the reduction of gender equality is not so much the outcome of the improvement of women's working conditions but of the worsening situation of men. On the other hand, austerity measures worsened the situation of women in terms of economic dependence with the reprivatization of care due to cuts in social and health services, increasing costs of care services and reductions in maternity and parental leave benefits (European Women's Lobby 2012).

The diminishing family income and the retrenchment of the welfare state create an extra burden on families where women play a significant role. The erosion of the welfare state is compensated by the 'welfare society' (Santos 1999, p. i). This means that public responsibilities of care are moving from the public to the private sphere (for example, childcare, housework, elderly care) and the private sphere is still predominantly women's responsibility. The participation of women in the labour market is variable in Europe (particularly visible in the differences between Hungary, Portugal and Turkey - see Hungler and Kende 2018; Meneses et al. 2018b; Yilmaz et al. 2018). While in Portugal women have the heavy burden of combining family care and jobs, in Hungary and Turkey they are encouraged to stay at home, as it is very difficult to conciliate both work and care, and are in a very disadvantaged situation when compared with men.

\subsection{RESISTANCES, PROTESTS, ALTERNATIVES}

António Casimiro Ferreira (2011) argues that in addition to the economic and financial aspects of the austerity model, there is also a social model of naturalization of inequalities. This new 'austerity society' is characterized by (1) fear as a source of legitimacy; (2) the emergence of a new constellation of power that combines elected and unelected power; and (3) destabilization of the normative structure with the use of a law of exception. Legitimacy by fear, 
prompted by predictions of catastrophic scenarios, asserts itself as a mechanism for converting the narrative of austerity into a dominant political-social model, assuring the absolute priority of the moral values of economic and labour neoliberalism, and by consequence of misdistribution. Casimiro Ferreira uses an expression of the Mozambican writer Mia Couto that poetically states that 'there is more fear of bad things than bad things themselves', along with the idea that 'there are those who fear the end of fear' (Mia Couto, quoted in Ferreira 2011, p. 132).

Empirical work made very clear how traditional inequalities and exclusions were reinforced with some groups being particularly affected by the economic crisis, like women, persons with disabilities, migrants or Roma. Young people, in general, especially the generation that grew up with the European promises of progress, became a very vulnerable working mass, available to accept almost anything in order to have a job. Plans for the future are put on hold and survival in the present is a permanent struggle between precarious jobs and family help. The ideas of fear are very clearly expressed though in different ways in the cases of Austria, the Netherlands and Portugal (Meier and Apostolovski 2018; Meneses et al. 2018b; de Vries et al. 2018). The first was subjected to lighter austerity measures than the other two but in all cases fear, disappointment and a sense of hopelessness became a constitutive element in citizens' lives.

The narrative of the absence of alternatives combined with the threat of a future that will certainly be worse than the present might have unexpected consequences. On one side of the coin, there is fear and resignation, on the other there is a strong perception of injustice. Europe disappointed its citizens and if no solution is being given and the promises fail, citizens will be more open to narratives of hope even if they contradict the European project values and the idea of the Union. It is impossible not to see a correlation of austerity and the success of right-wing populist discourses. The promise of a future that might be different has to garner sympathy when the discourse of democratic institutions does not provide a more justice-based alternative.

However, in a first moment, the perception of injustice also led to strong public protests mobilized by a young and well-educated European generation that was raised under the promises of democracy, rights and opportunities. Below the excerpt of a letter written by a Spanish organization called 'Youth with no Future' (Juventud sin Futuro) is presented:

We grew up listening to how our country had entered into an age of modernity and wellbeing, that we were the better prepared generation and the one with more capabilities, and that the rights conquered by those who came before us would be extended and generalized ... For the first time, the crisis has shown to the generation born of those who did the transition, the weaknesses of the political and economic model we live in, the falsity in promises of more well-being, and the vulnerability of 
the rights our parents passed on to us but, in most cases, have not taught us to stand for ... The time to turn this situation around has come: this is the time for the generation to whom the future was stolen to fight for its rescue. (Juventud Sin Futuro 2013)

Austerity policies in Portugal before and after the Troika intervention pushed people into the streets in numbers that had no precedent in the Portuguese consolidated democracy. In Portugal, one of the mobilizers of the first big protest of 2011 explained, in an interview, the inspirational strength was that of the Arab Spring. The Arab Spring was about major changes in non-democratic contexts, it was about contradicting an imposed fate. A message was being sent to the world about struggle and resistance. An open letter to civil society by the organizers of one of the anti-austerity protests in Portugal states:

We will not neglect the structural, domestic and international problems that affect many people's lives in the search for employment. We want to alert for the urgency of rethinking national strategies and we do not resign in face of the arguments of the absence of alternatives to this situation. It is with a sense of responsibility that we, as the most qualified generation ever, want to be part of the solution. ${ }^{5}$

Many protests that spread throughout Europe and movements like Occupy and Indignados defended a real democracy that is not compatible with rules dictated by financial markets. If European institutions and their leaders claimed that austerity was the only way and national governments ruled according to that, protesters were discussing something different. They were not looking for solutions for the crisis inside of the current model, they wanted to discuss a new model of democracy and representative justice that is open to the voices of citizens and takes seriously the values inscribed in European treaties and national constitutions.

However, if some movements pointed to the structural deviations of the EU and argued for radical transformations with a revolutionary impetus, it is also true that many people and organizations acknowledge the need for reforming existing welfare state institutions in order to make them more resilient or to guarantee better life prospects for people. Several contested ideas, such as universal income, came back to the public discussion, addressing some of the most important debates such as the meaning and the future of work. Beyond the diverse and sometimes oppositional positions regarding the basic income guarantee proposal, the idea that all persons should be entitled to a basic income regardless of their work status, question the workfarist orientations, particularly as these become conditional for access to welfare benefits, and even what is socially valued and acknowledged as work (Meier and Apostolovski 2018). 


\subsection{CONCLUSION}

Before the crisis, and as expressed eloquently in the Lisbon Agenda, Europe wanted to stand out in the globalized world as an economy able to combine competitiveness and social cohesion. The European Social Model was an anchor, a proposal for an active role of the state in ensuring some levels of social protection for the population. With the programme of the social investment state articulated with the knowledge economy and society framework, the EU was able to tame the pressure of the Washington Consensus for deregulation and welfare retrenchment, by articulating discursively the positive role of social policies in economic growth. This, however, did not mean that welfare states were not being qualitatively reformed to abandon important elements of redistribution via decommodification as the orientation to workfare became dominant. Social policies became seen no longer as a remedy for market externalities or a hindrance to the economy but as a tool for economic growth. Social rights-based citizenship regimes were transformed in social investment regimes. The consequences of not having the citizens and social justice as the main motivation for social investment, but economic growth, is that distributive policies became less secured. Social and economic rights become dependent on the market's mood and its impact on each country.

The crisis did not hit everyone in the same way, neither did the 'one size fits all' character of the austerity and structural adjustment reforms. Countries were affected in different ways as they started from different starting points and went through different austerity levels and structural adjustment measures. There are also different forms and intensities of exclusion inside each country. It must be kept in mind that policies and laws, even when enrolled in a common discourse, may have different results according to each country's position in the European economy and citizens' position inside civil society. The ideal of flexicurity is an excellent example to understand different consequences for the same discourse. Raised before the crisis, flexicurity was inspired by Dutch and Danish experiences and proposed the combination of flexibility in the labour market with social security. Though it seemed an acceptable shift that would not jeopardize the equality values of Europe, in practice only a few countries could accomplish both flexibility and security. It was not an exportable idea.

Briefly, the analysis carried out for this chapter clearly suggest that misrecognition and vulnerabilization of labour and social protection (misdistribution) in the name of austerity is perpetrated through institutionalized patterns - in other words, through the workings of the institutions that regulate interactions (Fraser 2000, p. 114). Indeed, notwithstanding the effects that a general reorientation towards austerity became a structural characteristic of EU governance, the countries which experienced more difficulties and harder 
deregulation policies in welfare and labour rights are those which already experienced stronger neoliberal transformations, be it the UK, the Central/ Eastern European countries, Turkey or the Southern European countries under international intervention for neoliberal structural adjustments. Within countries, some social groups were more affected than others by the crisis and austerity such as young people and women, already typically in a disadvantageous situation in the labour market and in the economy. Gender discrimination tends to reinforce all other inequalities and vulnerabilities. As a recent Oxfam report states, in the aftermath of a crisis:

women are more exposed to gender-based violence, more likely to lose their jobs or be pushed into lower-paid work and more vulnerable to losing social benefits and protections, including pensions. Women are also more likely to increase the amount of unpaid care work that they do when measures to cut public spending are introduced. (OXFAM 2020, p. 40)

In short, the outcome is, therefore, the intensification of polarization both between and inside countries. Without properly funded organizations giving voices to young people and women, more human and just economic models will be increasingly hard to achieve.

\section{NOTES}

1. Lisbon European Council, 23 and 24 March 2000, Presidency Conclusions, accessed 4 December 2018 at http://www.europarl.europa.eu/summits/lis1_en. htm.

2. Available at http://www.oecdbetterlifeindex.org, accessed 8 May 2018.

3. Involuntary part-time workers are those working part-time only because they could not find a full-time job.

4. Other self-employed categories include business owners, liberal professionals or farmers (Eurofound 2018).

5. Protest of the Generation in Distress (Geração à Rasca), accessed 22 March 2018 at https://geracaoenrascada.wordpress.com/2011/03/04/convite-a-sociedadecivil/.

\section{REFERENCES}

Abrahamson, Peter (2010), 'European welfare states beyond neoliberalism: toward the social investment state', Development and Society, 39 (1), 61-95.

Andreotti, Alberta, Soledad Mariso Garcia, Aitor Gomez, Pedro Hespanha, Yuri Kazepo and Enzo Mingione (2001), 'Does a Southern European Model exist?', Journal of Contemporary European Studies, 9 (1), 43-62.

Bekker, Sonja (2018), 'Flexicurity in the European Semester: still a relevant policy concept?', Journal of European Public Policy, 25 (2), 175-92.

Brandl, Bernd and Barbara Bechter (2019), 'The hybridization of national collective bargaining systems: the impact of the economic crisis on the transformation of 
collective bargaining in the European Union', Economic and Industrial Democracy, 40 (3), 469-89.

Cerami, Alfjo (2008), 'Central Europe in transition: emerging models of welfare and social assistance', MPRA Paper No. 8377, accessed 8 March 2018 at https://mpra.ub .uni-muenchen.de/8377/1/MPRA_paper_8377.pdf.

Commission of the European Communities (1997), Modernising and improving social protection in the European Union. Communication from the Commission, COM (97) 102 final. Brussels.

Costa, Ana and José Castro Caldas (2014), 'A União Europeia e Portugal entre os resgates bancários e a austeridade: um mapa das políticas e das medidas', in José Reis (ed.), A Economia Política do Retrocesso: Crise, Causas e Objectivos. Coimbra: Almedina, pp. 72-107.

Dupont, Pier-Luc and Bridget Anderson (2018), 'UK report on the claims, interests and capabilities of young mothers and migrant domestic workers in economic debates', country report for ETHOS report D6.2 (unpublished).

Esping-Andersen, Gøsta (1999), Social Foundations of Postindustrial Economies. New York: Oxford University Press.

Eurofound (2017), Occupational Change and Wage Inequality: European Jobs Monitor 2017. Luxembourg: Publications Office of the European Union.

Eurofound (2018), Non-Standard Forms of Employment: Recent Trends and Future Prospects. Luxembourg: Publications Office of the European Union.

European Commission (2015), Communication from the Commission to the European Parliament, the Council and the European Central Bank On steps towards Completing Economic and Monetary Union, COM(2015) 600 final.

European Council (2017), European Pillar of Social Rights: Proclamation and Signing, accessed 8 March 2020 at https://www.consilium.europa.eu/en/press/press-releases/ 2017/11/17/european-pillar-of-social-rights-proclamation-and-signing/.

European Union (2012), Progress on Equality between Women and Men in 2011. A Europe 2020 Initiative. Luxembourg: Publications Office of the European Union.

European Women's Lobby (2012), The Price of Austerity - the Impact on Women's Rights and Gender Equality in Europe. Brussels: EWL.

Ferreira, António Casimiro (2011), 'A sociedade de austeridade: Poder, medo e direito do trabalho de exceção', Revista Crítica de Ciências Sociais, 95, 119-36.

Ferrera, Maurizio, Martin Rhodes and Anton Hemerijck (2001), The Future of Social Europe: Recasting Work and Welfare in the New Economy. Oeiras: Celta.

Fraser, Nancy (2000), 'Rethinking recognition', New Left Review, 3, 107-20.

Gallie, Duncan (2013), Economic Crisis, the Quality of Work, \& Social Integration: The European Experience. Oxford: Oxford University Press.

Giddens, Anthony (1998), The Third Way: The Renewal of Social Democracy. Cambridge: Polity Press.

Hermann, Christoph (2017), 'Crisis, structural reform and the dismantling of the European Social Model(s)', Economic and Industrial Democracy, 38 (1), 51-68.

Hungler, Sara and Agnes Kende (2018), 'Roma on public work contract case study in Hungary and young women with caring responsibilities in Hungary', country report for ETHOS report D6.2 (unpublished).

Jenson, Jane (2010), 'Diffusing ideas for after neoliberalism: the Social investment perspective in Europe and Latin America', Global Social Policy, 10 (1), 59-84.

Jenson, Jane and Denis Saint-Martin (2003), 'New routes to social cohesion? Citizenship and the social investment state', Canadian Journal of Sociology, 28 (1), 77-99. 
Jessop, Bob (2013), 'Putting neoliberalism in its time and place: a response to the debate', Social Anthropology, 21 (1), 65-74.

Juncker, Jean Claude, Donald Tusk, Jeroen Dijsselbloem, Mario Draghi and Martin Schulz (2015), Completing Europe's Economic and Monetary Union. Brussels: European Commission.

Juventud sin Futuro (2013), 'Letter to the Europeans from Juventud Sin Futuro (Youth without a Future)', Letters to the Europeans. Coimbra: Alice CES, accessed 8 March 2018 at http://alice.ces.uc.pt/en/wp-content/uploads/2013/06/Letter-to-the -europeans-Book.pdf.

Leite, Jorge, Hermes Augusto Costa, Manuel Carvalho da Silva and João Ramos de Almeida (2014), 'Austeridade, reformas laborais e desvalorização do trabalho', in José Reis (ed.), A Economia Política do Retrocesso: Crise, Causas e Objectivos. Coimbra: Almedina, pp. 127-88.

Lima, Maria da Paz Campos (2015), 'A reconfiguração do regime de emprego e de relações laborais em Portugal na Ótica Liberal', Cadernos do Observatório, 5.

Meier, Irene and Veronika Apostolovski (2018), 'Universal minimum wages as instruments to foster just income distribution on the Austrian labour market?', country report for ETHOS report D6.2 (unpublished).

Meneses, Maria Paula, Sara Araújo, Sílvia Ferreira and Barbara Safradin (2018a), 'Comparative report on the types of distributive claims, interests and capabilities of various groups of the population evoked in the political and economic debates at the EU and at the nation state level', ETHOS report D6.2, accessed 2 September 2019 at https://www.ethos-europe.eu/.

Meneses, Maria Paula, Sara Araújo and Laura Brito (2018b), 'Portuguese report on distributive justice claims', country report for ETHOS D6.2 (unpublished).

OXFAM (2020), Time to Care. Unpaid and Underpaid Care Work and the Global Inequality Crisis. Oxford: OXFAM.

Prosser, Thomas (2017), 'Insiders and outsiders on a European scale', European Journal of Industrial Relations, 23 (2), 135-50.

Santos, Boaventura de Sousa (1999), 'Sociedade-Providência ou autoritarismo social?', Revista Crítica de Ciências Sociais, 42, i-viii.

Vaughan-Whitehead, Daniel (ed.) (2015), The European Social Model in Crisis: Is Europe Losing Its Soul?, Cheltenham, UK and Northampton, MA, USA: Edward Elgar Publishing.

Vries, Sybe de, Barbara Safradin and Roemer Sijmons (2018), 'Netherlands report on the claims, interests and capabilities of young women with care burdens and refugees in their struggles for social distributive justice', country report for ETHOS report D6.2 (unpublished).

Wilthagen, Ton and Frank Tros (2004), "The concept of "flexicurity": a new approach to regulating employment and labour markets', Transfer: European Review of Labour and Research, 10 (2), 166-86.

Yilmaz, Volkan, Başak Akkan, Alpkan Birelma and Simla Serim (2018), 'Young women and people with disabilities in the labour market. The case of Turkey', country report for ETHOS report D6.2 (unpublished). 